It was stressed that participants were there in their individual capacities and not on behalf of governments, but that they suggested policies and programmes which were practicable in terms of administration.

\title{
The Zanzibar Government Archives and Museum
}

THE first report, for the year 1956, of the newly combined Zanzibar Archives and Museum Department continues the series of reports on the work of the Peace Memorial Museum. The museum was originally opened in 1925 , with an extension in I 930 devoted primarily to the natural history of Zanzibar. This annexe also contains the museum library and a small laboratory.

The successful development of the museum in its early days was due to its first curator Dr. A. H. Spurrier, assisted by Dr. W. M. Aders, and since then many Zanzibar residents have devoted time and energy to increasing its collections. In 1953 a special committee recommended that the possibility of setting up a Zanzibar Archives should be given urgent consideration, and in $1956 \mathrm{Mr}$. C. H. Thompson, who had previously been responsible for the establishment of the Government Archives in Nyasaland, was appointed Zanzibar Government Archivist and Curator of the Peace Memorial Museum.

The main difficulties to be overcome have been the accumulation of papers and the destruction of many of these by insect pests, against whom constant wat must be waged. Much of the correspondence between the British Consulate, the Foreign Office, and the Bombay Government from 1840 onwards is intact and reasonably well preserved. The Consulate archives, however, have long since lost their original archival sequence; it is hoped to rearrange these at least chronologically and to compile a brief indexed inventory. A system is being worked out for the planned retirement of all records worthy of permanent preservation when they have ceased to be of immediate administrative interest. Existing accumulations of obsolete papers are to be worked over in each government department and guidance will be given on what must be preserved and what may be destroyed.

In the Museum itself attention has been concentrated on improving the administration and on sorting the accumulation of papers. It is hoped that time and money will be available to re-present some of the exhibits and to obtain new specimens for the natural history collections. The museum's collection of Zanzibar and Pemba beads has been examined and classified by Dr. van der Sleen of Naarden, Holland, who considers that many are 'trade wind' or 'barter' beads dating from A.D. 600 to 1000, brought to Africa on the monsoon winds by traders from the east. The identification of coins is being carried out by Mr. Freeman-Grenville, and by Dr. J. Walker, Keeper of Coins and Medals in the British Museum. The finding of Roman coins in Pemba may or may not be of archaeological significance, for there are many feasible explanations, but it is interesting to note that Dr. van der Sleen has drawn attention to one of the beads in the museum's collectiona transparent glass 'melon' bead-of a type found throughout the Mediterranean littoral and also in central Europe wherever Roman settlements were established.

Zanzibar's position on trunk shipping routes has made the museum very widely known and it has attracted visitors from all parts of the world.

\section{Centenary of the Niger Mission}

The Niger Mission of the Church Missionary Society celebrated its Centenary on 16 November 1957. In a message to Bishop C. J. Patterson (Bishop on the Niger) and Bishop E. T. Dimieari (Bishop of the Niger Delta), the Secretary of State for the Colonies, Mr. Alan Lennox-Boyd, paid tribute to the devoted work of the Anglican Church in Nigeria. He pointed out that the government of the country is already largely in the hands of Nigerians, 
and that in this, as in so much else, the Church has led the way, for Samuel Crowther was himself an African and the work once begun by missionaries from overseas is increasingly being carried out by the men and women of Nigeria themselves.

\section{East African Institute of Social Research Conference, June I957}

THE following papers were given at the East African Institute of Social Research's summer conference: Social class in modern Buganda, by L. A. Fallers; The rise of the Uganda African Farmers' Union in Buganda, by A. B. Mukwaya; The report of the Income Tax Commission, by David Walker; Regional disparities of income and taxation in Uganda, by W. Elkan; Some problems of change amongst the Kuria, by M. J. Ruel; A history of relations between the Arusha and the Masai, by P. H. Gulliver; Recent researches amongst the Masai, by Alan H. Jacobs; The structure of Shambalai, by E. V. Winans.

\section{Sierra Leone's first Festival of Arts}

THE festival of arts held in Freetown in December revealed and encouraged the creative talents of the people of Sierra Leone in a wide variety of crafts, ranging from carving, weaving, dyeing, and leatherwork to tribal dancing. Sir Gordon Russell, Director of the Council of Industrial Design, lectured and adjudicated in some of the competitions. During the festival Sierra Leone's Museum was officially opened. Among its exhibits are the crown of Paramount Chief Jaia Kaikai I, a statute of Madame Yoko (Paramount ruler of the Kpa Mende from 188 , to 1906), and the original Royal Charter of 1799 which gave Freetown its mayor.

\section{Lamu and the East African Dhow Traffic}

DR. A. H. J. PrINs, Reader in Cultural Anthropology in the State University of Groningen, Netherlands, has just completed a six months' study of the social and economic organization of the East African dhow trade and its implications for the population of the Lamu Islands off the coast of northern Kenya. This is the first modern analysis of one of the Islamic coastal communities, the study of which was judged to be urgent and long overdue in a recent assessment of current and necessary research in East Africa (see Africa, xxvi. 3, 1956, pp. 271, 275). Before embarking on this study in May, Dr. Prins also had an opportunity to visit the Persian Gulf area, with which the African coast is most intimately connected by the seasonal traffic of the ocean-going dhows. Part of the results of the present field study will be incorporated in his forthcoming section on the Swahili, which is to appear in the Institute's Ethnographic Survey series. The Lamu study, together with Professor Grottanelli's researches among the Northern Bajun, also an important component of the population of the Lamu area, means that up-to-date material on the northern part of the coastal civilization will now be available. Moreover, Dr. P. Lienhardt is at present engaged in field research among the Arabs of Zanzibar, and Dr. G. Wilson, the Kenya Government sociologist, has completed his social survey of Mombasa town. It may therefore be expected that our knowledge of an African culture area so long neglected will shortly be enlarged to a very considerable extent.

[Communicated by Dr. A. H. J. Prins]

Researches at I.R.S.A.C.

A stuDY of the history of Ruanda and Urundi is being undertaken by M. Jan Vansina in co-operation with M. l'Abbé Kagame. M. A. A. Trouwborst, who is due to arrive at I.R.S.A.C. in January, is to study the political structure of Urundi, with special reference to 